\title{
Analysis of the Influence of Sources on the Spatial Variation in Atmospheric Methane Concentrations in the City of Tandil, Argentina
}

\section{Victoria Susana Fusé}

Centro de Investigaciones en Física e Ingeniería del Centro de la Provincia de Buenos Aires, Argentina

Carla Sofia Stadler

Centro de Investigaciones en Física e Ingeniería del Centro de la Provincia de Buenos Aires.

Natasha Picone

Centro de Investigaciones Geográficas

Santiago Linares

Centro de investigaciones Geográficas

Sergio Alejandro Guzman

Facultad de Ciencias Exactas, UNCPBA

Maria Paula Juliarena ( $\sim$ pjuliarena@exa.unicen.edu.ar)

CIFICEN ( CONICET- UNCPBA- CICPBA) https://orcid.org/0000-0003-2923-1163

\section{Research Article}

Keywords: Methane, Urban area, Spatial analysis tools, Natural gas, Sources

Posted Date: September 27th, 2021

DOl: https://doi.org/10.21203/rs.3.rs-883555/v1

License: (1) This work is licensed under a Creative Commons Attribution 4.0 International License.

Read Full License 


\section{Abstract}

There is an overall trend in urban methane $\left(\mathrm{CH}_{4}\right)$ emissions due to the presence of several sources; however, differences exist between cities, and therefore further local research should be undertaken. The present study analyzes the spatiotemporal variation in atmospheric $\mathrm{CH}_{4}$ concentrations during a year at ten sampling sites in the urban core of a medium-sized city. The mean annual atmospheric $\mathrm{CH}_{4}$ concentrations varied between $2.02 \mathrm{ppm}$ and $5.45 \mathrm{ppm}$; the maximum concentrations were found in a site close to a wastewater treatment plant (WWTP), presenting a significant increase toward the summer. In the rest of the sites, the maximum concentrations were recorded in the coldest months due to the influence of combustion sources dependent on natural gas (NG). An exploratory regression analysis was performed, in which the variables "homes connected to the gas network" and "distance from compressed NG stations" each explained 66 and $65 \%$ of the spatial variation of the atmospheric $\mathrm{CH}_{4}$ concentrations at the 9 sites (excluding that one nearest the WWTP). The results show the need to prevent NG leaks in all urban areas to reduce the emissions of this potent greenhouse gas, which, at the same time, will provide economic benefits for the sectors involved.

\section{Introduction}

The task of reducing greenhouse gases (GHGs) emissions sufficiently to stabilize their atmospheric concentrations and therefore mitigate climate change is a great global challenge (Erickson 2017). Methane $\left(\mathrm{CH}_{4}\right)$ becomes relevant because its atmospheric concentrations continue to increase, making it the second most important anthropogenic GHG in terms of climate forcing, after carbon dioxide $\left(\mathrm{CO}_{2}\right)$ (Saunois et al. 2020).

$\mathrm{CH}_{4}$ emission reduction is technically challenging: it demands identifying each source, quantifying its emission flux, and developing effective emission reduction methodologies (Nisbet et al. 2020). $\mathrm{CH}_{4}$ is emitted by a variety of processes, including natural and anthropogenic ones, and by a variety of sources, fixed and diffuse, non biogenic and biogenic, thermogenic and pyrogenic ones (Saunois et al. 2020). The goal should be to reduce anthropogenic emissions, which we can control (Nisbet et al. 2019).

Cities generate $70 \%$ of anthropogenic GHGs emissions, a fraction that is growing with global urbanization (Hopkins et al. 2016). Because of their density, efficiency, and adoption of innovations and new technologies, cities can provide solutions for reducing emissions (Hoornweg et al. 2011). The effectiveness of these remedial actions depends on accurate knowledge of the many sources of GHG in each city (Ars et al. 2020). In many cities, estimating the source contribution when so many emission sources coexist, can be challenging. Besides, according to Nisbet et al. (2020), the location of emissions may be complex because what initially appears to be a point source may actually comprise many small sub-sources.

In general, the urban sources of GHGs can be classified in energy (electricity, heating), industry (processes, product use), transportation (road, non-road, navigation, take-offs, landings, and aircraft flying 
over urban areas), and waste (landfills, wastewater treatment) (Marcotullio et al. 2013). Energy and transportation emit primarily fossil $\mathrm{CH}_{4}$ derived from natural gas (NG) (Balcombe et al. 2017; Cai et al. 2017; Bo Zhang et al. 2014), whereas waste treatment produces biogenic $\mathrm{CH}_{4}$ from the process of anaerobic decomposition (El-Fadel and Massoud 2001). Leaks in the NG distribution network and low efficiency during gas use (for heating, for cooking, or as vehicle fuel) contribute greatly to anthropogenic $\mathrm{CH}_{4}$ emissions (Fusé et al. 2019; Hendrick et al. 2016; Hopkins et al. 2016, Hu et al. 2018, Saint-Vincent and Pekney 2019; Wong et al. 2016). Compared with other fuels, compressed NG (CNG) is economically attractive, and as a result, the number of CNG vehicles has notably increased in the past years (Kumar et al. 2015). In the waste sector, $\mathrm{CH}_{4}$ emissions depend mainly on the waste generated (its kind and volume), waste separation and disposal, the number of homes, and the socioeconomic level of the population (Ranieri et al. 2017; Yan et al. 2019; Zhao et al. 2019).

GHGs emissions are significantly associated with population size, density, growth rates, and per capita income (Marcotullio et al. 2013). At present, cities are undergoing a profound transformation that especially affects the territorial structures of their peripheries (Palomares and Puebla 2007; Linares and Picone 2018). The expansión of urban peripheries gradually results in population decentralization, and separation between daily activities and access to services (Rufí 2003). This urban expansion is accompanied by the emergence of new pollution emission sources (Hien et al. 2020), which causes significant spatial and temporal variations in the atmospheric concentration of contaminant gases (Hien et al. 2020; Norman et al. 2006). The development and application of models that allow quantifying the interrelationships between environmental and socioeconomic factors associated with urban growth will help us to learn about the possible future effects of their evolution, key to preventing associated problems (Linares 2019). Although there are overall trends in urban $\mathrm{CH}_{4}$ emissions, differences exist between cities (geophysical factors-climate, access to resources-and technical factors, such as power generation, urban design, waste processing), which need to be explored by further local research (Kennedy et al. 2009).

In Argentina, some authors have conducted studies on GHG emissions in specific urban sectors: waste (Sanci and Panarello 2016), NG residential use (Fusé et al. 2019), and transport (Puliafito et al. 2015). In general, the GHG inventories that Argentina submits to the United Nations Framework Convention on Climate Change (UNFCCC) secretariat, following IPCC guidelines, are based on data and emission factors that do not apply to this region (Secretariat of the Environment and Sustainable Development 2015). This leads to considerable uncertainty about the national GHG emission budget.

The aim of this study is to identify possible $\mathrm{CH}_{4}$ sources in a medium-sized city in order to explain the spatial variability of atmospheric $\mathrm{CH}_{4}$ concentrations. For it, periodical measurements were performed in several strategically selected urban sites, and then, using spatial analysis tools, the relative contribution of $\mathrm{CH}_{4}$ from each source was evaluated.

\section{Materials And Methods}




\section{The Study Site}

Tandil city $\left(37^{\circ} 19^{\prime} \mathrm{S}, 59^{\circ} 08^{\prime} \mathrm{W}\right.$; with an area of $52.34 \mathrm{~km}^{2}$ and a population of 116.916$)$ is located in the southcenter of Buenos Aires province, Argentina. To measure atmospheric $\mathrm{CH}_{4}$ concentration, 10 sampling sites were selected (Fig. 1a), ensuring a uniform distribution over the urban area that would include different urban densities, residential and commercial uses of soil (Figs. $1 \mathrm{~b}$ and $1 \mathrm{C}$ ), and $\mathrm{CH}_{4}$ sources (Fig. 2).

For the meteorological characterization of the study period, data regarding air temperature, relative humidity, atmospheric pressure, visibility, and wind velocity were obtained daily from the National Meteorological Service, Tandil-AERO weather station. In addition, information on NG monthly consumption-CNG, residential, commercial, and public consumption by different sectors of the city was provided by the only NG supplier (CAMUSSI S.A).

\section{Monitoring of atmospheric $\mathrm{CH}_{4}$ concentrations}

During a study period of one year (June 1st, 2017 - May 31st, 2018), integrated air samples were obtained in consecutive 15-day periods. The samples were collected in 0.5 liter stainless steel canisters with an inlet valve (Fusé et al. 2019) and an air flow controller calibrated for the desired sampling period (Gere and Gratton 2010). The canisters were previously cleaned with high purity nitrogen and evacuated to approximately $0.5 \mathrm{mb}$ pressure. At the end of each sampling period, the canisters were replaced and transferred to the laboratory, where samples were analyzed for $\mathrm{CH}_{4}$ concentration by gas chromatography (CG Agilent 7890A) (Fusé et al. 2019). Regarding measurement error, the chromatograph ranges from $1 \%$ to $3 \%$ (0.02 to $0.05 \mathrm{ppm}$ for ambient air).

\section{Data analysis and statistics}

Basic descriptive statistical analyses were performed to assess temporal and spatial variation in atmospheric $\mathrm{CH}_{4}$ concentrations measured in each sampling site. An ANOVA Test and a Fisher's LSD test were performed to examine temporal differences between atmospheric $\mathrm{CH}_{4}$ concentrations measured in each site and analyze the differences between sampling sites (mean values with the same letter are not statistically different). The relative incidence of biogenic and non biogenic sources in the atmospheric $\mathrm{CH}_{4}$ concentrations at each site was measured using the Pearson correlation analysis with ambient temperature and with NG sectoral consumption. For all the analyses a p-value of 0.05 was considered to assess significance. Infostat Statistical software was used for all statistical analyses.

\section{Exploratory Regression}

Spatial analysis tools (ArcGIS 10.5®) were used to identify the independent variables that account for the mean $\mathrm{CH}_{4}$ values obtained. First, georeferencing of the sampling sites was performed. To assess the influence of the environment on each sampling site, a buffer zone (area of influence) was created around 
each one (Hoek et al. 2008). We selected a buffer radius of $300 \mathrm{~m}$, following the recommendations by several authors (Briggs et al. 2000; Henderson et al. 2007).

Based on the last National Census of Population and Housing in the city of Tandil (INDEC 2010), we calculated the average of homes connected to the NG network (GN) within each census tract that included one of the buffers at the sampling sites (Fig. 2a). In addition, the fixed sources that could a priori contribute to the spatial variation in atmospheric $\mathrm{CH}_{4}$ concentrations in the urban area-CNG stations, a wastewater treatment plant (WWTP) and an artificial lake, were represented in a vector layer, and the Euclidean distance to each sampling site was calculated. In this way, three individual maps were created: distance in meters from the CNG station (GD), from the WWTP (PD), and from the artificial lake (LD) (Figs. 2b, 2c and 2d).

Taking into account that the dependent variable is the mean $\mathrm{CH}_{4}$ concentrations in each site (seasonal and annual) and that the independent variables are the four layers created, an exploratory regression analysis was performed. This tool examines whether the association between variables is constant in the whole urban area or whether variations take place with the goal of looking for the Ordinary Least Squares (OLS) models that best explain the dependent variable (Habermann et al. 2015; Bertazzon et al. 2015). Such a relationship can be positive or negative in sign (directly or inversely proportional) with a high or low $\%$ of significance of the variable (consistency in the relationships). To validate the results (passing models), the coefficients considered were the following: the adjusted $R^{2}$ (Adj $R^{2}$ ) $>0.50$, the level of significance $p<0.05$, the Variance Inflation Factor $(\mathrm{VIF}$, that indicates independence between the independent variables) $<7.5$, the spatial autocorrelation I Global Moran with $p>0.10$ and the residual normality summary Jarque-Bera with $p>0.10$ (Buzai and Baxendale 2012; Quinn and Keough 2002; Rosenshein et al. 2011). It should be noted that for all OLS indices a significance level of $p<0.01$ was used.

\section{Results And Discussion}

\section{Meteorological parameters and natural gas consumption}

Over the study period, mean monthly temperature was $14.6^{\circ} \mathrm{C}$, with a variation range from 8.5 to $21.4^{\circ} \mathrm{C}$. Regarding humidity, air pressure and visibility the measured mean values were $71.0 \%, 1015.4 \mathrm{hPa}$ and $15.1 \mathrm{Km}$, respectively. Average total monthly rainfall was $78.1 \mathrm{~mm}$. Precipitation and air temperature presented the highest temporal variability (coefficient of variation equal to $32.2 \%$ and $42.3 \%$, respectively). Whereas precipitation showed no statistically significant differences between the 4 seasons $(p>0.05)$, temperature did show differences $(p<0.05)$ except in the fall and the spring. Wind intensity remained almost constant (mean monthly equal to $13.5 \mathrm{Km} \mathrm{h}^{-1}$ ) throughout the period and showed no statistically significant differences between seasons $(p>0.05)$, except for the fall.

Fig. 3 shows the temporal variation in monthly NG consumption in the city of Tandil for the residential, commercial, and CNG sectors during the study period. Of the total NG consumption in the city of Tandil, 
$65.2 \%, 10.6 \%, 10.0 \%$ and $14.1 \%$ correspond to the residential, commercial, CNG and industrial (not considered in this study) sectors, respectively. In Argentina, the highest percentages of consumption of NG distributed along the gas network correspond to the residential and industrial sectors $-43.5 \%$ and $39.7 \%$, respectively (Secretary of Energy of the Nation 2019).

NG residential and commercial consumption are higher in winter, with statistically significant differences in relation to the other seasons in the case of the residential sector and to spring and summer in the case of the commercial sector $(p<0.05)$. This behavior was reflected in a good correlation between NG consumption and ambient temperature, with an $R$ and $p$ value (value in parenthesis) of $-0.78(p=0.003)$ and -0.94 ( $p<0.0001)$ for the residential and commercial sectors, respectively. In general, heating degree days is currently an important determinant of the amount of energy required to heat urban buildings (Kennedy et al. 2009). In our country, residential and commercial NG consumption reaches its maximum level in the winter months (Secretariat of the Environment and Sustainable Development 2015).

Regarding CNG demand, only statistically significant differences were measured between summer and winter $(p<0.05)$, with a fairly good correlation with ambient temperature $(R=-0.69, p=0.013)$. A decrease in the CNG consumption in the summer is probably related to less economic activity as a consequence of the holidays (Gil 2006; Gioli et al. 2012).

\section{Temporal variability of atmospheric methane concentrations}

Table 1 shows the average atmospheric $\mathrm{CH}_{4}$ concentrations for each season and for the complete study period at each sampling site.

Table 1 Comparison of the mean values of the atmospheric $\mathrm{CH}_{4}$ concentrations between seasons $( \pm$ standard deviation, $\mathrm{n}$ = total number of measurements performed in each site, superscript letters show results for Fisher's LSD Test) and results of Pearson correlation analysis (linear correlation coefficients $\mathrm{R}$ and significance level $\mathrm{p}$ in parentheses) between the atmospheric $\mathrm{CH}_{4}$ concentrations and the mean air temperature $(T)$ at each site 
Site Atmospheric $\mathrm{CH}_{4}$ concentration (ppm)

$n \quad$ Pearson $\left[\mathrm{CH}_{4}\right]$ with $\mathrm{T}$

\begin{tabular}{|c|c|c|c|c|c|c|c|}
\hline & Spring & Summer & Fall & Winter & Annual & & $R(p)$ \\
\hline 1 & $\begin{array}{l}2.14 \pm \\
0.05^{\mathrm{a}}\end{array}$ & $\begin{array}{l}2.08 \pm \\
0.04^{\mathrm{a}}\end{array}$ & $\begin{array}{l}2.26 \pm \\
0.06^{\mathrm{ab}}\end{array}$ & $\begin{array}{l}2.45 \pm \\
0.37^{b}\end{array}$ & $\begin{array}{l}2.22 \pm \\
0.23\end{array}$ & 20 & $-0.71(<0.001)$ \\
\hline 2 & $\begin{array}{l}2.16 \pm \\
0.04^{\mathrm{a}}\end{array}$ & $\begin{array}{l}2.12 \pm \\
0.07^{a}\end{array}$ & $\begin{array}{l}2.36 \pm \\
0.12^{b}\end{array}$ & $\begin{array}{l}2.38 \pm \\
0.06^{\mathrm{b}}\end{array}$ & $\begin{array}{l}2.25 \pm \\
0.14\end{array}$ & 20 & $-0.92(<0.001)$ \\
\hline 3 & $\begin{array}{l}4.24 \pm \\
1.03^{\mathrm{a}}\end{array}$ & $\begin{array}{l}5.78 \pm \\
1.07^{b}\end{array}$ & $\begin{array}{l}6.18 \pm \\
2.03^{b}\end{array}$ & $\begin{array}{l}5.58 \pm \\
0.45^{\mathrm{ab}}\end{array}$ & $\begin{array}{l}5.45 \pm \\
1.41\end{array}$ & 20 & $-0.24(0.455)$ \\
\hline 4 & $\begin{array}{l}2.09 \pm \\
0.07^{a}\end{array}$ & $\begin{array}{l}2.08 \pm \\
0.04^{a}\end{array}$ & $\begin{array}{l}2.30 \pm \\
0.17^{b}\end{array}$ & $\begin{array}{l}2.27 \pm \\
0.04^{\mathrm{b}}\end{array}$ & $\begin{array}{l}2.19 \pm \\
0.14\end{array}$ & 20 & $-0.82(0.001)$ \\
\hline 5 & $\begin{array}{l}2.16 \pm \\
0.04^{\mathrm{a}}\end{array}$ & $\begin{array}{l}2.09 \pm \\
0.02^{\mathrm{a}}\end{array}$ & $\begin{array}{l}2.30 \pm \\
0.09^{b}\end{array}$ & $\begin{array}{l}2.30 \pm \\
0.08^{b}\end{array}$ & $\begin{array}{l}2.21 \pm \\
0.11\end{array}$ & 24 & $-0.93(<0.001)$ \\
\hline 6 & $\begin{array}{l}2.19 \pm \\
0.11^{\mathrm{a}}\end{array}$ & $\begin{array}{l}2.12 \pm \\
0.04^{\mathrm{a}}\end{array}$ & $\begin{array}{l}2.31 \pm \\
0.14^{\mathrm{a}}\end{array}$ & $\begin{array}{l}2.57 \pm \\
0.32^{b}\end{array}$ & $\begin{array}{l}2.30 \pm \\
0.24\end{array}$ & 24 & $-0.78(0.003)$ \\
\hline 7 & $\begin{array}{l}2.05 \pm \\
0.05^{\mathrm{a}}\end{array}$ & $\begin{array}{l}2.01 \pm \\
0.05^{a}\end{array}$ & $\begin{array}{l}2.22 \pm \\
0.24^{b}\end{array}$ & $\begin{array}{l}2.12 \pm \\
0.07^{\mathrm{ab}}\end{array}$ & $\begin{array}{l}2.10 \pm \\
0.14\end{array}$ & 24 & $-0.65(0.023)$ \\
\hline 8 & $\begin{array}{l}2.32 \pm \\
0.09^{a b}\end{array}$ & $\begin{array}{l}2.22 \pm \\
0.07^{a}\end{array}$ & $\begin{array}{l}2.46 \pm \\
0.17^{\mathrm{b}}\end{array}$ & $\begin{array}{l}2.45 \pm \\
0.09^{b}\end{array}$ & $\begin{array}{l}2.37 \pm \\
0.14\end{array}$ & 23 & $-0.66(0.020)$ \\
\hline 9 & $\begin{array}{l}2.11 \pm \\
0.02^{\mathrm{a}}\end{array}$ & $\begin{array}{l}2.09 \pm \\
0.05^{\mathrm{a}}\end{array}$ & $\begin{array}{l}2.26 \pm \\
0.10^{\mathrm{b}}\end{array}$ & $\begin{array}{l}2.31 \pm \\
0.16^{\mathrm{b}}\end{array}$ & $\begin{array}{l}2.19 \pm \\
0.13\end{array}$ & 24 & $-0.82(0.001)$ \\
\hline 10 & $\begin{array}{l}2.04 \pm \\
0.04^{\mathrm{b}}\end{array}$ & $\begin{array}{l}1.97 \pm \\
0.03^{\mathrm{a}}\end{array}$ & $\begin{array}{l}2.03 \pm \\
0.04^{\mathrm{b}}\end{array}$ & $\begin{array}{l}2.05 \pm \\
0.04^{\mathrm{b}}\end{array}$ & $\begin{array}{l}2.02 \pm \\
0.05\end{array}$ & 22 & $-0.79(0.003)$ \\
\hline
\end{tabular}

Except for S3 (the one nearest the WWTP and located in a high-density zone), at all sites the greatest $\mathrm{CH}_{4}$ concentrations were registered in the winter and/or the fall, with significant statistical differences with respect to the other seasons. A good inverse statistically significant correlation was obtained between the mean monthly atmospheric $\mathrm{CH}_{4}$ concentration at each site and monthly mean temperature (Table 1). Given that the maximum $\mathrm{CH}_{4}$ concentrations were recorded in the coldest months, we infer that the predominant sources are non biogenic ones, and not sources associated with biological processes, whose emissions occur in the warm seasons (Wong et al. 2016).

Fusé et al. (2019) suggested that the maximum concentrations of atmospheric $\mathrm{CH}_{4}$ recorded in the fall and winter in Tandil can be explained by the higher consumption of NG for heating and by gas leaks in the heating systems. In general, good statistically significant correlations were obtained between 
atmospheric $\mathrm{CH}_{4}$ and residential or commercial consumption of NG (Table 2). NG exhaust from diverse residential implements (for heating, water heating, and cooking) contains some unburned $\mathrm{CH}_{4}$ due to inevitable incomplete combustion (Lebel et al. 2020; Merrin and Francisco 2019). Helfter et al. (2016) suggest that in winter, increases in $\mathrm{CH}_{4}$ concentrations above the background level could be attributed to $\mathrm{CH}_{4}$ losses from over-pressurized pipelines as a response to an increase in gas demand.

Table 2 Linear correlation coefficients $\mathrm{R}$ and significance level $\mathrm{p}$ (in parentheses) between the values of atmospheric $\mathrm{CH}_{4}$ concentration for each site and the NG volumes for each sector

\begin{tabular}{llll}
\multicolumn{3}{l}{ Sector } & \\
\hline Site & Residential & Commercial & CNG \\
\hline 1 & $0.71(0.01)$ & $0.70(0.01)$ & $0.43(0.16)$ \\
\hline 2 & $0.58(0.05)$ & $0.93(<0.01)$ & $0.57(0.05)$ \\
\hline 3 & $-0.13(0.70)$ & $0.33(0.29)$ & $0.12(0.70)$ \\
\hline 4 & $0.48(0.11)$ & $0.77(<0.01)$ & $0.29(0.35)$ \\
\hline 5 & $0.61(0.04)$ & $0.92(0.03)$ & $0.57(0.05)$ \\
\hline 6 & $0.75(0.01)$ & $0.79(0.01)$ & $0.58(0.05)$ \\
\hline 7 & $0.30(0.33)$ & $0.58(0.05)$ & $0.08(0.80)$ \\
\hline 8 & $0.45(0.14)$ & $0.63(0.03)$ & $0.51(0.09)$ \\
\hline 9 & $0.67(0.02)$ & $0.84(<0.01)$ & $0.33(0.29)$ \\
\hline 10 & $0.68(0.02)$ & $0.62(0.03)$ & $0.44(0.15)$
\end{tabular}

A better correlation between atmospheric $\mathrm{CH}_{4}$ and commercial consumption of NG was obtained for $\mathrm{S} 2$, S4, S5 and S9, probably because these sites are located in commercial areas or close to them (La Macchia 2016). S9 is situated at one of the main entrances to the city, where various stores are located (Migueltorena and Linares 2019).

The best correlation between atmospheric $\mathrm{CH}_{4}$ and $\mathrm{CNG}$ demand was observed in S6. This site is located near National Route 226 and two CNG stations (Fig. 2b). A good correlation was also established for other sites close to CNG stations, S2, S5, and S8, although the last one with a value of $p<0.1$. In the CNG stations, $\mathrm{CH}_{4}$ emissions may result from the process of converting pipeline gas to vehicle fuel and during the fueling process itself. Recent surveys provide evidence for fugitive emissions in gas stationselevated $\mathrm{CH}_{4}$ levels (up to $14.1 \mathrm{ppm}$ ) were observed in a CNG vehicle gas station in Irvine, California (Hopkins et al. 2016). 
S3 is the only site for which no good correlation was found between the mean monthly atmospheric $\mathrm{CH}_{4}$ concentration and ambient temperature and between atmospheric $\mathrm{CH}_{4}$ concentration and monthly consumption of NG by any of the sectors. Chen et al. (2018) showed a relatively weak seasonality of $\mathrm{CH}_{4}$ emissions in the waste sector. However, the increase in atmospheric $\mathrm{CH}_{4}$ in the summer, compared with the winter and spring, seems to indicate a greater participation of biogenic sources within the WWTP (Kong et al. 2002). $\mathrm{CH}_{4}$ emissions tend to be high in summer, when biological production of $\mathrm{CH}_{4}$ increases due to relatively high water temperature (Masuda et al. 2015). The seasonal maximum in the fall could be attributed to the predominance of non biogenic sources, associated to NG use (Sánchez et al. 2018; Wong et al. 2016) or to a greater accumulation of the $\mathrm{CH}_{4}$ emitted by the WWTP resulting from possible thermal inversions (Verhulst et al. 2017). The latter may result from concurrent meteorological conditions (high humidity, reduced visibility, fog, low temperatures and wind intensity) (Ackerman and Knox 2006), which occur in Tandil in the fall (Picone 2014; Fusé et al. 2019). The dissimilar seasonal behavior and the relatively high atmospheric $\mathrm{CH}_{4}$ concentrations observed in $\mathrm{S} 3$ required that the following analyses be performed in two ways: including and excluding S3.

All these results appear to indicate the presence of one or more dominant sources that cause atmospheric $\mathrm{CH}_{4}$ concentrations in each site to vary across seasons. When considering the effect of ambient temperature on the mean monthly $\mathrm{CH}_{4}$ concentration (average of concentrations in the 10 sites), a good inverse correlation is obtained $(R=-0.79, p=0.002)$. Therefore, the use of NG seems to account for a large percentage of atmospheric $\mathrm{CH}_{4}$ in the urban area of Tandil, as was observed for a previous period (Fusé et.al. 2019). In turn, in Helfter et al. (2016), average $\mathrm{CH}_{4}$ fluxes in London were 17 \% lower in summer than in winter, but the correlation with air temperature was not statistically significant. This suggests that the total $\mathrm{CH}_{4}$ flux is due to a superposition of sources with constant and time-varying emission rates.

\section{Spatial analysis and exploratory regression of atmospheric $\mathrm{CH}_{4}$ concentrations}

\section{Mean seasonal atmospheric $\mathrm{CH}_{4}$ concentrations}

Based on the temporal variation of the atmospheric $\mathrm{CH}_{4}$ concentrations observed in each site, we explored differences between the sites for each season. According to the results of Fisher's LSD test, in spring, summer, and fall, atmospheric $\mathrm{CH}_{4}$ concentrations can be classified in only two categories: high (letter $b$ ) for S3, and low (letter $a$ ) for the rest of the sites. In winter, although S3 still presents the highest $\mathrm{CH}_{4}$ concentration, the concentrations measured in the other sites increase and the differences between the sites become more visible as a consequence (letters $a, b, c$ and $d$ in the results of Fisher's LSD test). This is in agreement with the results reported in Tables 1 and 2, which indicated a greater relevance of non biogenic sources associated with NG consumption during the coldest months. When repeating this analysis, excluding $\mathrm{S} 3$, the differences in atmospheric $\mathrm{CH}_{4}$ concentrations between sites for each season become more evident. $\mathrm{S} 8$ presented the highest atmospheric $\mathrm{CH}_{4}$ concentrations with statistically significant differences with respect to the other sites in spring and summer, and compared with $\mathrm{S} 7$ and 
$\mathrm{S} 10$ in the fall. In winter, the greatest atmospheric $\mathrm{CH}_{4}$ concentrations were measured in $\mathrm{S6}$, with statistically significant differences compared with S4, S5, S7, S9, and S10.

The spatial variation in the atmospheric $\mathrm{CH}_{4}$ concentrations measured in the city depends on the type of dominant source (fixed, diffuse, biogenic, or non biogenic), its relative contribution, and its distance from the sampling site (Carranza et al. 2018; Helfter et al. 2016). When performing the exploratory regression analysis on the 10 sites, no variable met all the search criteria established in section Exploratory Regression for each diagnostic test. However, some findings are worth noting. When performing it on 9 sites (excluding S3), the seasonal behavior of the sources that account for spatiotemporal variation becomes more notable (Table 3).

Table 3 Results of the exploratory regression analysis for the 9 study sites (excluding S3), by season and for the complete study period (annual): Homes connected to the gas network (GN); distance from CNG stations (GD), distance from the wastewater treatment plant (PD), distance from the artificial lake (LD) 
Variable Sign $\mathrm{p}$-value $\quad \operatorname{Adj}^{2} \quad \%$ Signif Passing Models

\begin{tabular}{|c|c|c|c|c|c|c|}
\hline \multirow[t]{4}{*}{ Winter } & \multicolumn{6}{|l|}{ LD } \\
\hline & GD & - & $\star \star \star \star$ & 0.59 & 37.5 & yes \\
\hline & PD & - & $\star *$ & 0.42 & 12.5 & \\
\hline & GN & + & $\star \star$ & 0.30 & & \\
\hline
\end{tabular}

Spring LD

$\begin{array}{llll}\mathrm{GD} & - & * & 0.28 \\ \mathrm{PD} & - & & 0.03\end{array}$

GN $\quad+\quad * * \quad 0.55 \quad 37.5 \quad$ yes

Summer LD

\begin{tabular}{llllll}
\hline $\mathrm{GD}$ & - & $\star \star$ & 0.53 & 25.0 & \\
\hline $\mathrm{PD}$ & - & & 0.14 & & \\
\hline $\mathrm{GN}$ & + & $\star \star \star$ & 0.77 & 75.0 & yes
\end{tabular}

Fall

LD 12.5

\begin{tabular}{llllll}
\hline $\mathrm{GD}$ & - & $\star \star \star$ & 0.70 & 37.5 & yes \\
$\mathrm{PD}$ & - & $*$ & 0.26 & 12.5 & \\
$\mathrm{GN}$ & + & $\star \star \star$ & 0.80 & 62.5 & yes
\end{tabular}

Annual LD

\begin{tabular}{llllll}
\hline $\mathrm{GD}$ & - & $\star \star \star$ & 0.65 & 37.5 & yes \\
$\mathrm{PD}$ & - & $*$ & 0.29 & & \\
\hline $\mathrm{GN}$ & + & $* \star *$ & 0.66 & 37.5 & yes
\end{tabular}

$\star=0.10, * \star=0.05, * \star \star=0.01$

The independent variable GD met the search criteria of each diagnostic test in the fall and winter, whereas GN in the spring and summer, as well as the fall (Table 3). Still, both variables significantly correlated with atmospheric $\mathrm{CH}_{4}$ concentrations with a value of $\mathrm{p}<0.05$ or $\mathrm{p}<0.10$ in those seasons when they failed to meet the search criteria. These results suggest that one source predominates over another according to the season. In winter, GD is the independent variable that best explains atmospheric $\mathrm{CH}_{4}$ concentrations, while in the spring and summer, the independent variable GN accounts for them. In the fall, both of these independent variables explain the spatial variations in atmospheric $\mathrm{CH}_{4}$ concentrations. The difference in 
the predominance of the sources for each season was more easily observed in the case of residential and commercial consumption of NG than in the CNG sector (Fig. 3). This behavior was reflected in Pearson correlations between atmospheric $\mathrm{CH}_{4}$ measured in each site and the general demand on NG for each use (Table 2); whereas in some sites residential or commercial demand on NG best explains the temporal variation in atmospheric $\mathrm{CH}_{4}$ concentrations, in other sites it is the demand on the CNG sector the variable that accounts for them.

The variable PD did not meet the search criteria for each diagnostic test in any season. When considering the 10 sites for the exploratory regression analysis, PD presented the highest values of $\operatorname{Adj~}^{2}{ }^{2}$ (between 0.29 and 0.37 ) in the four seasons. However, $P D$ significantly correlated with atmospheric $\mathrm{CH}_{4}\left(\operatorname{Adj} \mathrm{R}^{2}=\right.$ 0.37 and $p<0.10$ ) in $25 \%$ of the cases reported in winter. Besides, for the linear regressions of the seasonal means for the 9 sites, the Adj $R^{2}$ value for PD was higher only in winter, with a 0.42 value but only in $12.5 \%$ of the cases reported. The results suggest that PD alone accounts for the high atmospheric $\mathrm{CH}_{4}$ concentrations registered in $\mathrm{S} 3$ whereas it only partly explains the concentrations measured in the other sites (where other $\mathrm{CH}_{4}$ sources predominate), as the WWTP is close to only 3 sites of the sampling network (S2, S5 and S6). According to the results of the exploratory regression analysis, multicollinearity were not observed for GD and PD or GN and PD (VIF < 7.5); however, the results of the Pearson correlation test between mean monthly atmospheric $\mathrm{CH}_{4}$ and monthly consumption of $\mathrm{NG}$ by sector suggest that GD or $\mathrm{GN}$ probably best accounts for the high $\mathrm{CH}_{4}$ concentrations measured in these sites. This is reasonably expected especially in winter when the sources dependent on NG are the most relevant and the differences of atmospheric $\mathrm{CH}_{4}$ concentrations between the sites become smaller.

\section{Annual mean atmospheric $\mathrm{CH}_{4}$ concentrations}

The annual mean atmospheric $\mathrm{CH}_{4}$ concentration measured in $\mathrm{S} 3$ showed statistically significant differences compared with the other sites $(p<0.05)$. The second highest value, found in S8 (zone near a CNG station and with a high density of homes connected to the gas network) (Fig. 2), only presented statistically significant differences in relation to S3 and S10. The remaining sites showed intermediate annual mean atmospheric $\mathrm{CH}_{4}$ concentrations with no statistically significant differences between them $(p>0.05)$. The differences in atmospheric $\mathrm{CH}_{4}$ concentrations between sites become more evident when excluding S3 from the Fisher's LSD test. S8 now presented statistically significant differences with respect to all the sites $(p<0.05)$, except $S 6$. The rest of the sites presented intermediate annual mean atmospheric $\mathrm{CH}_{4}$ concentrations, although with minor differences between them (represented by the pairs of letters $a b, b c, c d$, de of Fisher's LSD test).

Because of these observations, the exploratory regression analysis performed for the seasonal mean atmospheric $\mathrm{CH}_{4}$ concentrations was repeated for the annual mean concentrations in order to explain the general $\mathrm{CH}_{4}$ behavior in the city of Tandil. Once again, when considering the 10 sites for the exploratory regression analysis, no variable met the search criteria of each diagnostic test. However, some findings 
are worth noting. When performing it on 9 sites (excluding S3), the variables GD and GN satisfied those criteria (Table 3).

Atmospheric $\mathrm{CH}_{4}$ concentration correlated positively with $\mathrm{GN}\left(\operatorname{Adj} \mathrm{R}^{2}=0.66, \mathrm{p}<0.01\right.$ ) and negatively with GD (Adj $\left.R^{2}=0.65, p<0.01\right)$. In Liu et al. (2019), population density had a remarkably positive correlation with $\mathrm{CH}_{4}$, with a correlation coefficient of $0.74(\mathrm{p}<0.01)$. As Sailor and Lu (2004) suggest, the anthropogenic heating profiles for the urban core would be correspondingly higher as they scale with population density. In Florence (Italy), road traffic and domestic heating were responsible for only $14 \%$ of the observed $\mathrm{CH}_{4}$ fluxes, while the major residual part was likely dominated by gas network leakages (Gioli et al. 2012). A study on the megacity of Seoul, Korea, confirmed the impacts of fugitive emissions on near-surface $\mathrm{CH}_{4}$ concentrations after the implementation of NG-powered vehicles (Nguyen et al. 2010).

PD explains $29 \%$ of the spatial variability of the atmospheric $\mathrm{CH}_{4}$ concentration in the city with a significance $p<0.10$. Similar results were reported by Liu et al. (2019), who found a negative correlation between $\mathrm{PD}$ and the atmospheric $\mathrm{CH}_{4}$ concentration with $\mathrm{R}^{2}=0.27$ and $\mathrm{p}<0.10$. When comparing both exploratory regressions for annual mean concentration, 10 sites vs. 9 sites, PD carried more weight in the first case (Adj $R^{2}=0.32$, although with $p>0.10$ and $25 \%$ of significance of the variable). The low values of $R^{2}$ and \% of significance of the variable are explained by the precise location of the source. Although both the WWTP and the CNG stations are fixed sources, these latter are located in different sites of Tandil city (Fig. 2b). For this reason, the CNG stations could generally contribute to the spatial variation in the atmospheric $\mathrm{CH}_{4}$ concentration in the city.

No significant correlations were established with LD $(p>0.1)$; this variable failed all the tests (Table 3$)$, proving not significant in this study. Although the urban lake was expected to acquire relevancy in the warmer months for being a biogenic $\mathrm{CH}_{4}$ source (Ortiz-Llorente and Alvarez-Cobelas 2012), its contribution was almost nonexistent because of its fixed location in an urbanized zone.

\section{Methane concentration associated with natural gas sources}

From the results of the exploratory regression, it can be observed that when 9 sites were considered, only the models with just one variable (GN and GD) were able to meet all the search criteria established in the diagnostic tests. The reason for this may be that one of these variables could best explain the temporal $\mathrm{CH}_{4}$ behavior in one site and, at the same time, have less relative weight in another site. For instance, the significance of GN and GD excluding S3 in the exploratory regression analysis for the entire study period was equal to $37.5 \%$ for both variables (Table 3 ). This accords with the results of the Pearson correlation test between mean monthly atmospheric $\mathrm{CH}_{4}$ in each site and monthly consumption of NG by each sector (residential, commercial, and CNG). The results reported in Liu et al. (2019) showed that the larger the population in the urban area, the greater the household energy consumption and the higher the $\mathrm{CH}_{4}$ emissions. Particularly, as observed by Hopkins et al. (2016), high levels of atmospheric $\mathrm{CH}_{4}$ were found 
near CNG storage tanks and connecting pipes in Orange County, California; however, $\mathrm{CH}_{4}$ increase was highly variable across the 12 different CNG stations surveyed, suggesting that fugitive leaks are responsible for these high concentrations.

In order to find a multiple OLS model that allows quantifying the interrelationships between both sources associated with NG consumption (GN and GD) and atmospheric $\mathrm{CH}_{4}$ concentration in the city of Tandil, it would be important to incorporate more sampling sites (Quinn and Keough 2002). These should be located not only within the urban core but also towards the periphery of the city to obtain a more precise atmospheric $\mathrm{CH}_{4}$ concentration for the entire city by increasing the measurement sites. Population density in urban cores is usually one order of magnitude higher than for the city as a whole (Liu et al. 2019). Furthermore, according to Marcotullio et al. (2013), the higher levels of $\mathrm{CH}_{4}$ emissions per capita in urban areas, compared with non-urban areas, are due to better energy and transportation infrastructure. Consequently, mean atmospheric $\mathrm{CH}_{4}$ concentrations and estimations per capita emissions may decrease when extending the sampling network toward the periphery. Nevertheless, it is necessary to consider that although the residential $\mathrm{CH}_{4}$ emissions are individually small, when taken together, the sector could contribute significantly to large-scale emissions (Saint-Vincent and Pekney 2019).

Estimating the relative $\mathrm{CH}_{4}$ contribution of sources associated with gas natural consumption, where several emission sources coexist, can be challenging. The spatial variation in atmospheric $\mathrm{CH}_{4}$ concentration will be the result of the combined effects of various relevant factors, such as traffic variables, population or address density, land use, altitude and topography, meteorology and location, as other authors suggest (Hoek et al. 2008; Liu et al. 2019; Nisbet et al. 2020). Data availability and the unique characteristics to each area will determine the choice of variables to be used in each study, so the inclusion of a $\mathrm{CH}_{4}$ source can be relevant in one city but not in another. In particular, the location of the WWTP in Tandil is in a densely populated area that deserves particular focus. A greater number of sampling sites around the WWTP would surely explain the spatial variability of atmospheric $\mathrm{CH}_{4}$ concentrations around this source. In addition, extending the sampling network to the periphery of the city would entail incorporating other fixed $\mathrm{CH}_{4}$ sources not included in this work (two WWTP and a landfill).

\section{Conclusion}

To explain spatial and temporal variations in the atmospheric $\mathrm{CH}_{4}$ concentrations in an urban site, it is important to learn about the predominance of the sources of this gas and about the nature of each source-whether it is biogenic or non biogenic, fixed or diffuse. Identifying the main sources responsible for the increase in atmospheric $\mathrm{CH}_{4}$ concentrations in a city helps to develop mitigation strategies. Although the WWTP is an important $\mathrm{CH}_{4}$ source, because it is a fixed source, it only explained $29 \%$ of the spatial variation of the annual mean atmospheric $\mathrm{CH}_{4}$ concentrations and the maximums registered during the summer. The variables "distance from CNG stations" and "number of homes connected to the gas network" are the ones that best explained the spatial variability of the annual mean atmospheric $\mathrm{CH}_{4}$ 
concentrations (65\% and $66 \%$, respectively) in the urban core of the city of Tandil and the maximum concentrations registered during the fall and /or winter.

Although the sources associated with NG consumption (residential, commercial, and CNG) cause only minor increases in $\mathrm{CH}_{4}$ concentrations, they are scattered in the whole urban area, and together their relative contribution therefore increases. Improving the efficiency of each system involved, from NG distribution, residential and commercial consumption to CNG use in vehicles, would not only reduce the emissions of this potent greenhouse gas and its resulting impact on the environment, but would also reduce gas losses and consequently bring economic benefits to each of these sectors. Preventing NG leaks to reduce emissions in all urban areas should be a goal to achieve in the short term.

Based on the results shown here, we propose expanding the sampling network and also performing the same study adjusting the model using the same and other variables. Finally, the baseline atmospheric $\mathrm{CH}_{4}$ concentration for the urban area obtained in this study, would allow estimating how the city growth would contribute to atmospheric $\mathrm{CH}_{4}$ as a result of the relative increase of the number of sources in the periphery of the city. In this sense, the results obtained serve as an important reference for medium-sized cities in constant growth.

\section{Declarations}

\section{Ethics approval and consent to participate}

Not applicable

\section{Consent for publication}

Not applicable

\section{Availability of data and materials}

The datasets generated during the current study are available in the Mendeley Data repository: https://data.mendeley.com/datasets/c5n4k6ddw7/1. Fusé VS, Stadler CS, Picone N, Linares S, Guzmán SA, Juliarena MP (2021) Atmospheric methane concentrations in the urban core of a medium-sized city. Mendeley Data V1. https://doi.org/10.17632/c5n4k6ddw7.1

\section{Competing interests}

The authors declare that there is no conflict of interest.

\section{Funding}

This work was supported by the Secretary of Science, Art, and Technology (SECAT) of the National University of the Center of Buenos Aires Province (UNCPBA), Argentina [03-PIO-06D; 03-PIO-21D] and by 
the National Scientific and Technical Research Council (CONICET) of the Ministry of Science, Technology, and Innovation (MINCyT), Argentina [PUE-CIFICEN - 22920170100004CO].

\section{Authors' contributions}

Investigation and Methodology were performed by VSF. Formal analysis and Visualization were performed by VSF and CSS. Conceptualization was performed by VSF, SL and MPJ. SAG and MPJ provided the necessary resources to carry out the study. NP provided the necessary ArGIS resources to explain the spatial variability of the mean methane values obtained. Funding acquisition was performed by SL and MPJ. MPJ was responsible for project administration and Supervision. The first draft of the manuscript was written by VSF and all authors commented on previous versions of the manuscript. All authors read and approved the final manuscript.

\section{Acknowledgments}

The authors gratefully acknowledge the National Weather Service for meteorological data and Agostina de la Torre and Macarena Haure for their help, digitalizing some inputs used in this work. Carla S Stadler is a graduate student in the Environment and Health Applied Sciences Doctoral Program (DCAAS) at National University of the Center of Buenos Aires Province (UNCPBA), Argentina.

\section{References}

1. Ackerman S, Knox JA (2006) Meteorology: understanding the atmosphere, 2nd ed. Thomson Higher Education, Belmont

2. Ars S, Wunch D, Ajmeri T, Arrowsmith C, Beauregard G, Cruz R, et al (2020) Using atmospheric in situ mobile measurements to monitor urban methane emissions. EGU General Assembly Conference Abstracts, p. 19995

3. Balcombe P, Anderson K, Speirs J, Brandon N, Hawkes A (2017) The natural gas supply chain: the importance of methane and carbon dioxide emissions. ACS Sustainable Chemistry \& Engineering 5(1):3-20. https://doi.org/10.1021/acssuschemeng.6b00144

4. Bertazzon S, Johnson M, Eccles K, Kaplan G (2015) Accounting for spatial effects in land use regression for urban air pollution modeling. Spatial and spatio-temporal epidemiology 14:9-21. https://doi.org/10.1016/j.sste.2015.06.002

5. Bo Zhang, Chen G, Li J, Tao L (2014) Methane emissions of energy activities in China 1980-2007. Renewable and Sustainable Energy Reviews 29:11-21. https://doi.org/10.1016/j.rser.2013.08.060

6. Briggs DJ, de Hoogh C, Gulliver J, Wills J, Elliott P, Kingham S, Smallbone K (2000) A regressionbased method for mapping traffic-related air pollution: application and testing in four contrasting urban environments. Science of the Total Environment 253(1-3):151-167. https://doi.org/10.1016/S0048-9697(00)00429-0 
7. Buzai G, Baxendale C (2012) Capítulo 23: Análisis de regresión lineal múltiple espacial y su modelización mediante estimador kernel. In: Buzai G, Baxendale C (Eds) Análisis Socioespacial con Sistemas de Información Geográfica, 1st edn. Lugar Editorial, Ciudad Autónoma de Buenos Aires, pp. 263-288

8. Cai H, Burnham A, Chen R, Wang M (2017) Wells to wheels: Environmental implications of natural gas as a transportation fuel. Energy Policy 109:565-578. https://doi.org/10.1016/j.enpol.2017.07.041

9. Carranza V, Rafiq T, Frausto-Vicencio I, Hopkins FM, Verhulst KR, Rao P et al (2018) Vista-LA: Mapping methane-emitting infrastructure in the Los Angeles megacity. Earth System Science Data 10(1):653-676. https://doi.org/10.5194/essd-10-653-2018

10. Chen Z, Griffis TJ, Baker JM, Millet DB, Wood JD, Dlugokencky EJ et al (2018) Source partitioning of methane emissions and its seasonality in the US Midwest. Journal of Geophysical Research: Biogeosciences 123(2):646-659. https://doi.org/10.1002/2017JG004356

11. El-Fadel M, Massoud M (2001) Methane emissions from wastewater management. Environmental pollution 114(2):177-185. https://doi.org/10.1016/S0269-7491(00)00222-0

12. Erickson LE (2017) Reducing greenhouse gas emissions and improving air quality: Two global challenges. Environmental Progress \& Sustainable Energy 36(4):982-988. https://doi.org/10.1002/ep.12665

13. Fusé VS, Gere JI, Urteaga D, Juliarena MP, Guzmán SA, Gratton R (2019) Atmospheric Methane Concentration Allows Estimating Natural Gas Leaks in Heating Systems in Tandil, Argentina. Journal of environmental quality 48(3):762-769. https://doi.org/10.2134/jeq2018.05.0220

14. Gere JI, Gratton R (2010) Simple, low-cost flow controllers for time averaged atmospheric sampling and other applications. Latin American Applied Research 40:377-381

15. Gil S (2006) Gas Natural en la Argentina: presente y futuro. Revista Ciencia Hoy 17(101):26-36

16. Gioli B, Toscano P, Lugato E, Matese A, Miglietta F, Zaldei A, Vaccari FP (2012) Methane and carbon dioxide fluxes and source partitioning in urban areas: The case study of Florence, Italy.

Environmental Pollution 164:125-131. https://doi.org/10.1016/j.envpol.2012.01.019

17. Habermann M, Billger $M$, Haeger-Eugensson M (2015) Land use regression as method to model air pollution. Previous results for Gothenburg/Sweden. Procedia Engineering 115:21-28. https://doi.org/10.1016/j.proeng.2015.07.350

18. Helfter C, Tremper AH, Halios CH, Kotthaus S, Bjorkegren A, Grimmond CSB et al (2016) Spatial and temporal variability of urban fluxes of methane, carbon monoxide and carbon dioxide above London, UK. Atmospheric Chemistry and Physics 16(16):10543-10557. https://doi.org/10.5194/acp-1610543-2016

19. Henderson SB, Beckerman B, Jerrett M, Brauer M (2007) Application of land use regression to estimate long-term concentrations of traffic-related nitrogen oxides and fine particulate matter. Environmental science \& technology 41(7):2422-2428. https://doi.org/10.1021/es0606780 
20. Hendrick MF, Ackley R, Sanaie-Movahed B, Tang X, Phillips NG (2016) Fugitive methane emissions from leak-prone natural gas distribution infrastructure in urban environments. Environmental Pollution 213:710-716. https://doi.org/10.1016/j.envpol.2016.01.094

21. Hoornweg D, Freire M, Lee MJ, Bhada-Tata P, Yuen B (2011) Cities and climate change: responding to an urgent agenda. The World Bank, Washington D. C.

22. Hien PD, Men NT, Tan PM, Hangartner M (2020) Impact of urban expansion on the air pollution landscape: A case study of Hanoi, Vietnam. Science of The Total Environment 702:134635. https://doi.org/10.1016/j.scitotenv.2019.134635

23. Hoek G, Beelen R, De Hoogh K, Vienneau D, Gulliver J, Fischer P, Briggs D (2008) A review of land-use regression models to assess spatial variation of outdoor air pollution. Atmospheric environment 42(33):7561-7578. https://doi.org/10.1016/j.atmosenv.2008.05.057

24. Hopkins FM, Ehleringer JR, Bush SE, Duren RM, Miller CE, Lai CT et al (2016) Mitigation of methane emissions in cities: How new measurements and partnerships can contribute to emissions reduction strategies. Earth's Future 4(9):408-425. https://doi.org/10.1002/2016EF000381

25. Hu N, Liu S, Gao Y, Xu J, Zhang X, Zhang Z, Lee X (2018) Large methane emissions from natural gas vehicles in Chinese cities. Atmospheric Environment 187:374-380.

https://doi.org/10.1016/j.atmosenv.2018.06.007

26. INDEC (2010) Population and housing national census 2010. Provincia de Buenos Aires. Hogares por tipo de vivienda, según combustible utilizado principalmente para cocinar. Inst. Nac. Estad. Censos República Argentina, Ciudad Autónoma de Buenos Aires, Argentina

27. Kennedy C, Steinberger J, Gasson B, Hansen Y, Hillman T, Havranek M et al (2009) Greenhouse gas emissions from global cities. Environmental Science \& Technology 43(19):7297-7302. https://doi.org/10.1021/es900213p

28. Kong HN, Kimochi Y, Mizuochi M, Inamori R, Inamori Y (2002) Study of the characteristics of $\mathrm{CH} 4$ and $\mathrm{N} 2 \mathrm{O}$ emission and methods of controlling their emission in the soil-trench wastewater treatment process. Science of the Total Environment 290(1-3):59-67. https://doi.org/10.1016/S00489697(01)01058-0

29. Kumar M, Rattan G, Prasad R. (2015). Catalytic abatement of methane emission from CNG vehicles: an overview. Canadian Chemical Transactions 3(4):381-409.

10.13179/canchemtrans.2015.03.04.0227

30. La Macchia ML (2016) Capítulo 9: Diagnóstico y regularización del uso de suelo comercial. In: Linares S (coordinador) Soluciones espaciales a problemas sociales urbanos. Aplicaciones de Tecnologías de la Información Geográfica a la planificación y gestión municipal. Universidad Nacional del Centro de la Provincia de Buenos Aires, Tandil, pp. 117-125

31. Lebel ED, Lu HS, Speizer SA, Finnegan CJ, Jackson RB (2020) Quantifying Methane Emissions from Natural Gas Water Heaters. Environmental Science \& Technology 54(9):5737-5745. https://doi.org/10.1021/acs.est.9b07189

32. Linares S (2019) Modelos del crecimiento urbano. Boletín Red del GESIG. INIGEO, UNLu 
33. Linares S, Picone N (2018) Application of Remote Sensing and Cellular Automata Model to Analyze and Simulate Urban Density Changes. In: Weng, Quattrochi \& Gamba (Eds) Urban Remote Sensing. CRC Press, Boca Raton, pp 213-234

34. Liu M, Meng Z, She Q, Zhu X, Wei N, Peng X, Xu Q (2019) Spatial variability and determinants of atmospheric methane concentrations in the metropolitan city of Shanghai, China. Atmospheric Environment 214:116834. https://doi.org/10.1016/j.atmosenv.2019.116834

35. Marcotullio PJ, Sarzynski A, Albrecht J, Schulz N, Garcia J (2013) The geography of global urban greenhouse gas emissions: An exploratory analysis. Climatic Change 121(4):621-634. https://doi.org/10.1007/s10584-013-0977-z

36. Masuda S, Suzuki S, Sano I, Li YY, Nishimura O (2015) The seasonal variation of emission of greenhouse gases from a full-scale sewage treatment plant. Chemosphere 140:167-173. https://doi.org/10.1016/j.chemosphere.2014.09.042

37. Merrin Z, Francisco PW (2019) Unburned methane emissions from residential natural gas appliances. Environmental science \& technology 53(9):5473-5482.

https://doi.org/10.1021/acs.est.8b05323

38. Migueltorena A, Linares S (2019) Mercado del suelo urbano y producción del espacio residencial en la ciudad de Tandil, Argentina. Cuadernos de Vivienda y Urbanismo 12(23):1-30. http://dx.doi.org/10.11144/Javeriana.cvu12-23.msup

39. Nisbet EG, Manning MR, Dlugokencky EJ, Fisher RE, Lowry D, Michel SE et al (2019) Very strong atmospheric methane growth in the 4 years 2014-2017: Implications for the Paris Agreement. Global Biogeochemical Cycles 33(3):318-342. https://doi.org/10.1029/2018GB006009

40. Nisbet EG, Fisher RE, Lowry D, France JL, Allen G, Bakkaloglu S et al (2020) Methane mitigation: methods to reduce emissions, on the path to the Paris agreement. Reviews of Geophysics 58(1):e2019RG000675. https://doi.org/10.1029/2019RG000675

41. Norman J, MacLean HL, Kennedy CA (2006) Comparing high and low residential density: life-cycle analysis of energy use and greenhouse gas emissions. Journal of urban planning and development 132(1):10-21. https://doi.org/10.1061/(ASCE)0733-9488(2006)132:1(10)

42. Nguyen HT, Kim KH, Ma CJ, Cho SJ, Sohn JR (2010) A dramatic shift in $\mathrm{CO}$ and CH4 levels at urban locations in Korea after the implementation of the Natural Gas Vehicle Supply (NGVS) program. Environmental Research 110(4):396-409. https://doi.org/10.1016/j.envres.2010.03.002

43. Ortiz-Llorente MJ, Alvarez-Cobelas M (2012) Comparison of biogenic methane emissions from unmanaged estuaries, lakes, oceans, rivers and wetlands. Atmospheric Environment 59:328-337. https://doi.org/10.1016/j.atmosenv.2012.05.031

44. Palomares JCG, Puebla JG (2007) La ciudad dispersa: cambios recientes en los espacios residenciales de la Comunidad de Madrid. Anales de geografía de la Universidad Complutense 27(1):45-67

45. Picone N (2014) Clima urbano de la ciudad de Tandil. Ph.D. diss., Universidad. Nacional del Sur 
46. Puliafito SE, Allende D, Pinto S, Castesana P (2015) High resolution inventory of GHG emissions of the road transport sector in Argentina. Atmospheric Environment 101:303-311.

https://doi.org/10.1016/j.atmosenv.2014.11.040

47. Quinn GP, Keough MJ (2002) Experimental design and data analysis for biologists. Cambridge university press, Cambridge

48. Ranieri E, Montanaro C, Ranieri AC, Campanaro V, Cioca LI (2017) Municipal solid wastes in the south-eastern mediterranean region: quality, quantity and management. Quality - Access to Success 18:162-169

49. Rosenshein L, Scott L, Pratt M (2011) Finding a meaningful model. ArcUser 14(1):40-45

50. Rufí J (2003) ¿Nuevas palabras, nuevas ciudades?. Revista de Geografía 2:79-103.

51. Sailor DJ, Lu L (2004) A top-down methodology for developing diurnal and seasonal anthropogenic heating profiles for urban areas. Atmospheric environment 38(17):2737-2748.

https://doi.org/10.1016/j.atmosenv.2004.01.034

52. Saint-Vincent PM, Pekney NJ (2019) Beyond-the-Meter: Unaccounted Sources of Methane Emissions in the Natural Gas Distribution Sector. Environmental Science \& Technology 54(1):39-49. https://doi.org/10.1021/acs.est.9b04657

53. Sanci R, Panarello HO (2016) Carbon stable isotopes as indicators of the origin and evolution of CO2 and $\mathrm{CH} 4$ in urban solid waste disposal sites and nearby areas. Environmental Earth Sciences 75(4):294. https://doi.org/10.1007/s12665-015-4906-5

54. Sanchez NP, Zheng C, Ye W, Czader B, Cohan DS, Tittel FK, Griffin RJ (2018) Exploratory study of atmospheric methane enhancements derived from natural gas use in the Houston urban area. Atmospheric Environment 176:261-273. https://doi.org/10.1016/j.atmosenv.2018.01.001

55. Saunois M, Stavert AR, Poulter B, Bousquet P, Canadell JG, Jackson RB et al (2020) The global methane budget 2000-2017. Earth System Science Data 12(3):1561-1623. https://doi.org/10.5194/essd-12-1561-2020

56. Secretariat of Energy of the Nation (2019) Balance Energético Nacional. República Argentina

57. Secretariat of the Environment and Sustainable Development of the Nation (2015) Tercera comunicación nacional de la República Argentina a la Convención marco de las naciones unidas sobre el cambio climático. República Argentina

58. Verhulst KR, Karion A, Kim J, Salameh PK, Keeling RF, Newman S et al (2017) Carbon dioxide and methane measurements from the Los Angeles Megacity Carbon Project-Part 1: calibration, urban enhancements, and uncertainty estimates. Atmospheric chemistry and physics 17. https://doi.org/10.5194/acp-17-8313-2017

59. Wong CK, Pongetti TJ, Oda T, Rao P, Gurney KR, Newman S et al (2016) Monthly trends of methane emissions in Los Angeles from 2011 to 2015 inferred by CLARS-FTS observations. Atmospheric Chemistry and Physics 16(20):13121-13130. https://doi.org/10.5194/acp-16-13121-2016

60. Yan X, Qiu D, Zheng S, Cheng K, Han Y, Sun J, Su X (2019) Spatial and temporal distribution of greenhouse gas emissions from municipal wastewater treatment plants in China from 2005 to 2014. 
Earth's Future 7(4):340-350. https://doi.org/10.1029/2018EF001058

61. Zhao X, Jin XK, Guo W, Zhang C, Shan YL, Du MX et al (2019) China's urban methane emissions from municipal wastewater treatment plant. Earth's Future 7(4):480-490.

https://doi.org/10.1029/2018EF001113

Figures
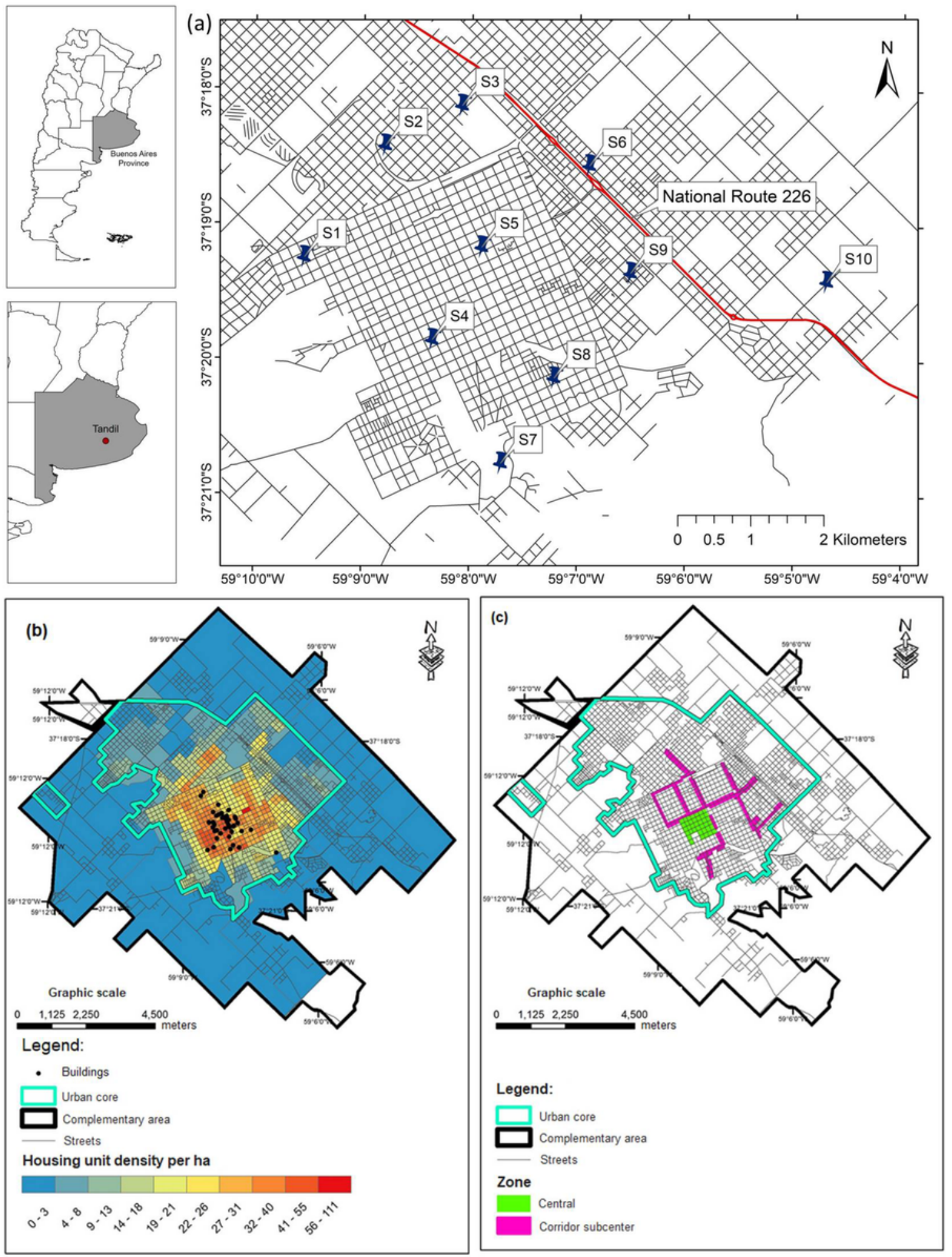


\section{Figure 1}

a Geographical location of the sampling sites; $b$ residential areas and c commercial areas in Tandil city [Migueltorena and Linares 2019]
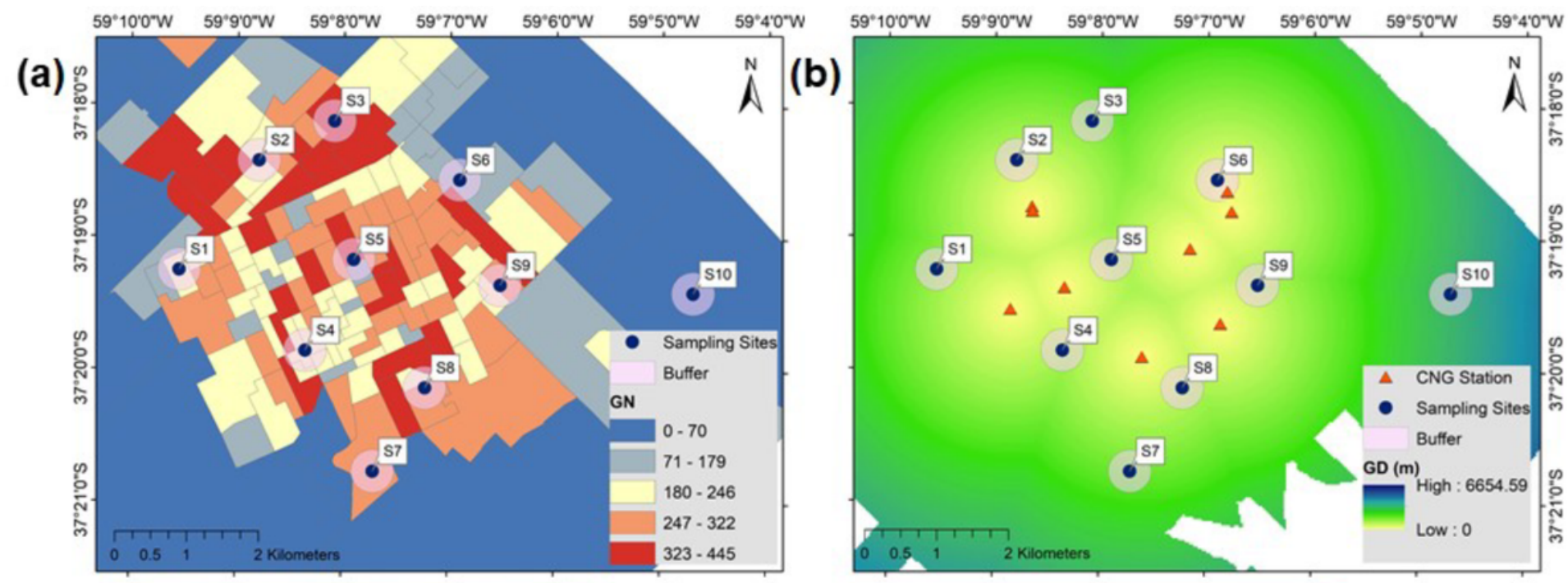

(c)

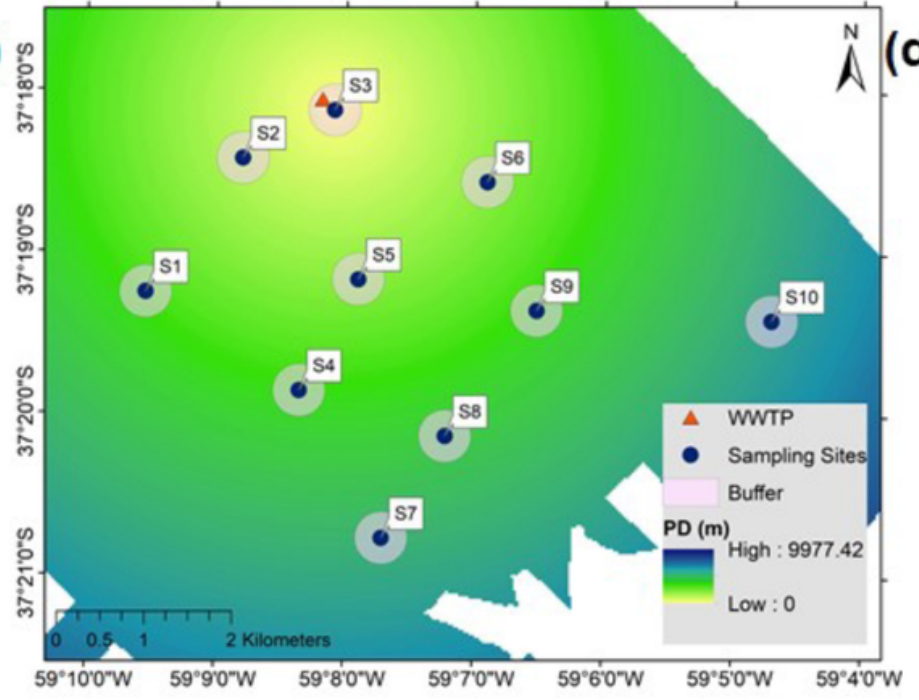

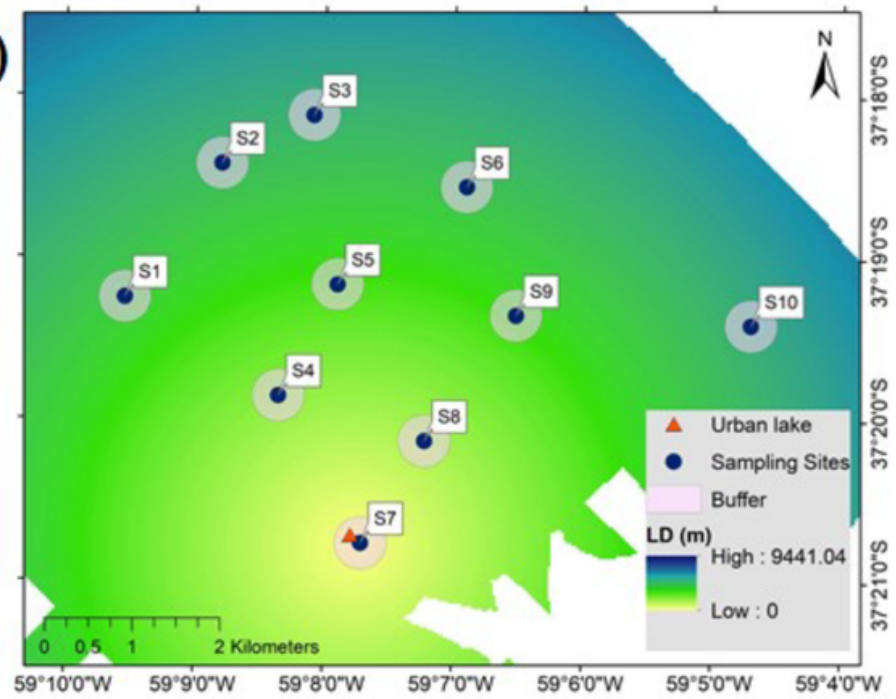

Figure 2

Sampling sites and Geographical Information System (GIS) layers: a number of homes that use gas for cooking within census tract (natural gas network, GN) (INDEC 2010); b distance from CNG station (GD); C distance from wastewater treatment plant (PD); d distance from the urban lake (LD) 


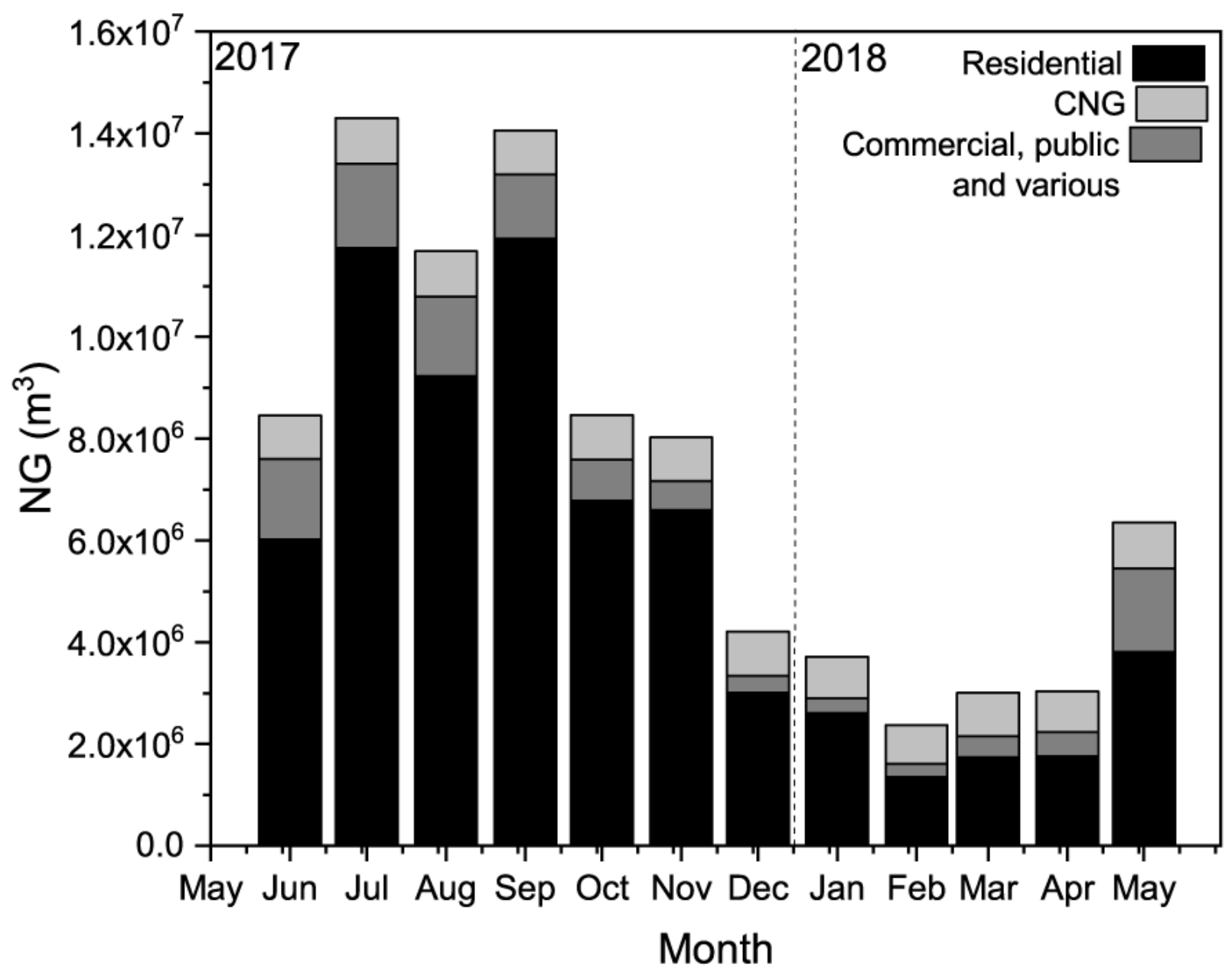

Figure 3

Natural gas (NG) consumption in cubic meters (m3) for each sector (residential, compressed NG [CNG], commercial, public, and various) 